\title{
Acoustic radiation force impulse (ARFI) elastography of the stifle joint
} of healthy beagles

[Elastografia acoustic radiation force impulse (ARFI) da articulação do joelho de beagles saudáveis]

\author{
L.M.I. Diogo ${ }^{1}$, C.R. Andrade ${ }^{1}$, L.G. Faria ${ }^{1}$, R.A.R. Uscategui ${ }^{2}$, M.C. Maronezi ${ }^{1}$, I.K. Cruz ${ }^{1}$, \\ L.P.N. Aires ${ }^{1}$, R.P. Nociti ${ }^{3}$, L.G.G.G. Dias ${ }^{1}$, M.A.R. Feliciano ${ }^{1,4^{*}}$, B.W. Minto \\ ${ }^{1}$ Faculdade de Ciências Agrárias e Veterinárias - Universidade Estadual Paulista - Jaboticabal, SP \\ ${ }^{2}$ Universidade Federal dos Vales do Jequitinhonha e Mucuri - Teófilo Otoni, MG \\ ${ }^{3}$ Faculdade de Engenharia de Alimentos e Zootecnia - Universidade de São Paulo - São Paulo, SP \\ ${ }^{4}$ Universidade Federal de Santa Maria - Santa Maria, RS
}

\begin{abstract}
The objective was to establish the reference standards for elastography of the main structures of the canine stifle joint. The medial meniscus, patellar and cruciate ligaments of thirty healthy beagles was evaluated by B-mode and ARFI elastography ( $n=60$ joints). Analysis detected a positive correlation of the shear wave velocity (SWV) of structures according to age. Patellar ligament presented a gradual stiffness increase in relation to age, while medial meniscus and cruciate ligament were more rigid in puppies than in adults. However, greater stiffness of these structures was observed in elderly animals. Elasticity of each structure was evaluated according to gender and reproductive status. Females presented greater stiffness of all structures, with SWV differing 0.3 and $0.36 \mathrm{~m} / \mathrm{s}$ between genders. Only the medial meniscus was not stiffer in neutered animals when compared to intact animals, differing only $0.02 \mathrm{~m} / \mathrm{s}$ in menisci and 0.4 to $0.47 \mathrm{~m} / \mathrm{s}$ in ligaments between groups. These findings corroborate with literature data that states a higher prevalence of ligament insufficiency in elderly dogs, females and neutered animals. It was concluded that ARFI elastography of the canine stifle joint is feasible and its application can be potentially effective in early diagnosis of ligament and meniscal changes.
\end{abstract}

Keywords: canine, femorotibiopatellar joint, joint ultrasonography

\section{RESUMO}

O objetivo foi estabelecer os padrões normais para elastografia das principais estruturas da articulação do joelho em cães. O menisco medial, ligamento patelar e cruzado de trinta beagles saudáveis foram avaliados pelo modo $B$ e elastografia ARFI ( $n=60$ articulações). A análise detectou uma correlação positiva da velocidade de cisalhamento $(S W V)$ das estruturas com a idade. O ligamento patelar apresentou um aumento gradual da rigidez em relação à idade, enquanto o menisco medial e o ligamento cruzado foram mais rígidos em filhotes do que em adultos. Entretanto, observou-se maior rigidez dessas estruturas em idosos. A elasticidade de cada estrutura foi avaliada de acordo com o sexo e o estado reprodutivo. As fêmeas apresentaram maior rigidez em todas as estruturas, com $S W V$ diferente de 0,3 e $0,36 \mathrm{~m} / \mathrm{s}$ entre os sexos. Somente o menisco medial não foi mais rígido nos animais castrados quando comparado não castrados, diferindo apenas $0,02 \mathrm{~m} / \mathrm{s}$ no menisco e 0,4 a $0,47 \mathrm{~m} / \mathrm{s}$ nos ligamentos entre os grupos. Esses achados corroboram com dados da literatura que afirmam maior prevalência de insuficiência ligamentar em cães idosos, fêmeas e animais castrados. Concluiu-se que a elastografia ARFI da articulação do joelho canino é viável e sua aplicação pode ser eficaz no diagnóstico precoce de alterações ligamentares e meniscais.

Palavras-chave: canino, articulação femorotibiopatelar, ultrassonografia articular

Recebido em 2 de março de 2020

Aceito em 23 de junho de 2020

*Autor para correspondência (corresponding author)

E-mail: marcusfeliciano@yahoo.com.br 


\section{INTRODUCTION}

The high prevalence of stifle joint injuries in dogs is due to its morphostructural characteristics and the strength to which they are submitted. Among its components, the cranial cruciate ligament has great importance in joint stability and its insufficiency causes a cascade of events that chronically culminate in degenerative joint disease (Prada et al., 2018).

Nowadays, imaging modalities, such as conventional ultrasonography, allow evaluation of physical ligament discontinuity and its physical and/or biomechanical consequences, however, they are not capable of evaluating the composition and structural modifications of the ligament itself and adjacent structures (Mariano and Loughin, 2010). Elastography is a diagnostic method that allows qualitative and quantitative measurements of the mechanical properties of tissues, specifically their stiffness, assessing structure elasticity (Holdsworth et al., 2014). In veterinary medicine, studies regarding this technique are recent, especially concerning small animal locomotive system, where only the patellar ligament of healthy dogs was studied (Piccionello et al., 2018).

Considering that stifle joint ligament abnormalities have been treated as degenerative disease, in which chronicity of the injuries and their consequences (hyalinization, mineralization, loss of fibroblasts and chondroid metaplasia of the remnants) may promote changes in tissue morphological and elastic characteristics (Duval et al., 1992), it is believed in the diagnostic potential of the ARFI technique for accurate joint evaluation in sick dogs.

It is hypothesized that elastography is feasible in determining stiffness of the canine stifle joint structures, which will present different aspects according to the age group evaluated. Thus, the present study aimed to standardize elastographic values of the stifle joint structures (patellar ligament, medial meniscus, cranial and caudal cruciate ligaments) of healthy Beagles in different age groups and reproductive status.

\section{MATERIAL AND METHODS}

This study was performed after approval from the Ethics Committee in Animal Use, under protocol
016524/17. Animals belonged to the Laboratory of Animal Nutrition from the institution. Thirty Beagle dogs were selected for the study. Animals were considered healthy based on general physical examination, hematological profile, orthopedic physical examination and radiographic study of the stifle joints. Orthopedic examinations included the assessment of ambulation and palpation of musculoskeletal structures, analyzing in the knee, signs of pain, changes in joint amplitude, edema, pseudocreptation, lateral shear, cranial tibial compression test, draw test (with extended and flexed limb) and patellar palpation.

The dogs were divided into three different groups: G1: healthy young animals, 6 to 12 months-old; G2: adults, 1 to 6 years-old; and G3: elderly, over 7 years-old. Hair was clipped on the stifle joint of all animals for imaging study. An ultrasound conductive gel was applied over the region of interest and all evaluations were performed by a single experienced operator (MARF). For B-mode evaluation of the stifle joint, a $9,0 \mathrm{MHz}$ linear transducer and ACUSON S2000/SIEMENS ultrasound machine were used. Dogs were manually contained, without need of sedation or fasting.

During the exam, patients were kept in lateral recumbency with the limb being evaluated contrary to the table. By means of goniometry, stifle joint angle in flexion and extension of each animal was measured and the mean value obtained was considered the anatomic angulation to be maintained during the evaluation. The medial meniscus, however, was evaluated in total flexion. For stifle joint elastography a $9.0 \mathrm{MHz}$ linear transducer was used, with the software for quantitative characterization using the ARFI method. Elastographic evaluation of each ligament was performed in longitudinal view, with the transducer positioned parallel and medial to the patellar ligament, angulation ranging from $0^{\circ}$ to $20^{\circ}$ in lateral direction (Figure 1). The medial meniscus was evaluated in transverse view, with the transducer perpendicular and slightly medial to the patellar ligament.

Quantitative elastographic evaluation determined the SWV. For that, an appropriated function in the system was determined in three regions of interest to cover the whole length of the stifle joint, in which an electronic caliper (ROI $-10 \mathrm{~mm}^{2}$ ) was positioned. Using this methodology, the software 
automatically calculated SWV in $\mathrm{m} / \mathrm{s}$ of each region, so mean values were obtained for statistical analysis (Figure 2).

Statistical analysis was performed using the $\mathrm{R}$ software $(\mathrm{R} \circledast$ foundation for statistical computing, Austria) and according to the recommendations of Chen and Peace (2010) and Petrie and Watson (2013). After confirmation of non-parametric data structure with Shapiro-Wilk test of normality, was decided to use the multiple comparison with Kruskal-Wallis test with post hoc test using the Fisher's least significant and Benjamini-Hochberg multiple testing adjustment (Benjamini and Hochberg, 1995) implemented in agricoloae R package (Mendiburu, 2020 ), being considered significant for the adjusted $\mathrm{P}<0.05$ (p.adj <0.05).

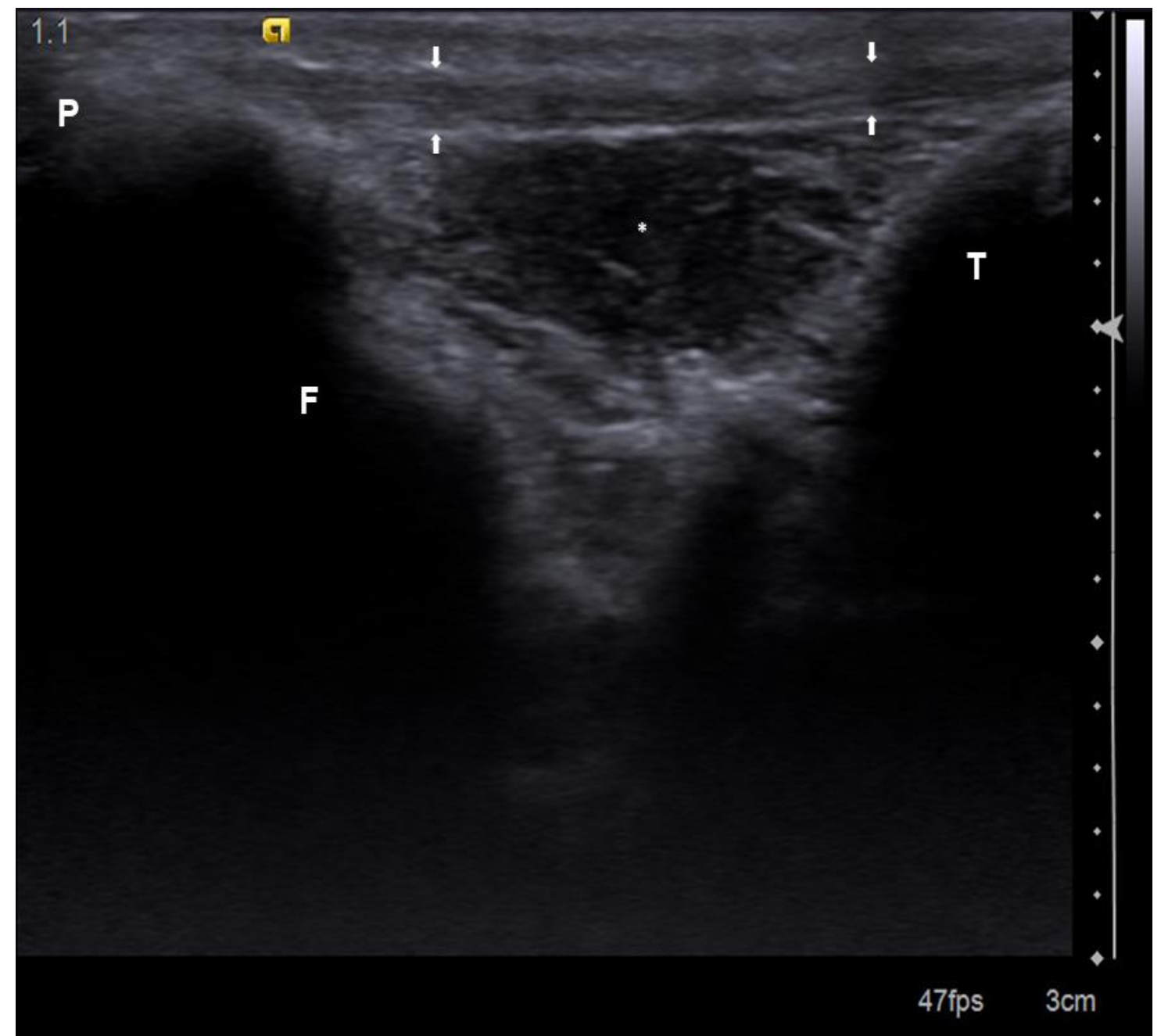

Figure 1. B-mode image of the infrapatellar region of the canine stifle joint. The patellar ligament (arrowheads) appears as a linear structure, slightly hypoechoic, or even isoechoic to the adjacent structures, connecting the patella $(\mathrm{P})$ to the tibia $(\mathrm{T})$ at the level of the tibial crest. The infrapatellar fat pad has a coarse echotexture and is hypoechoic to the adjacent tissue. It is located caudal to the patellar ligament and between the femur (F) and the tibia (T). 


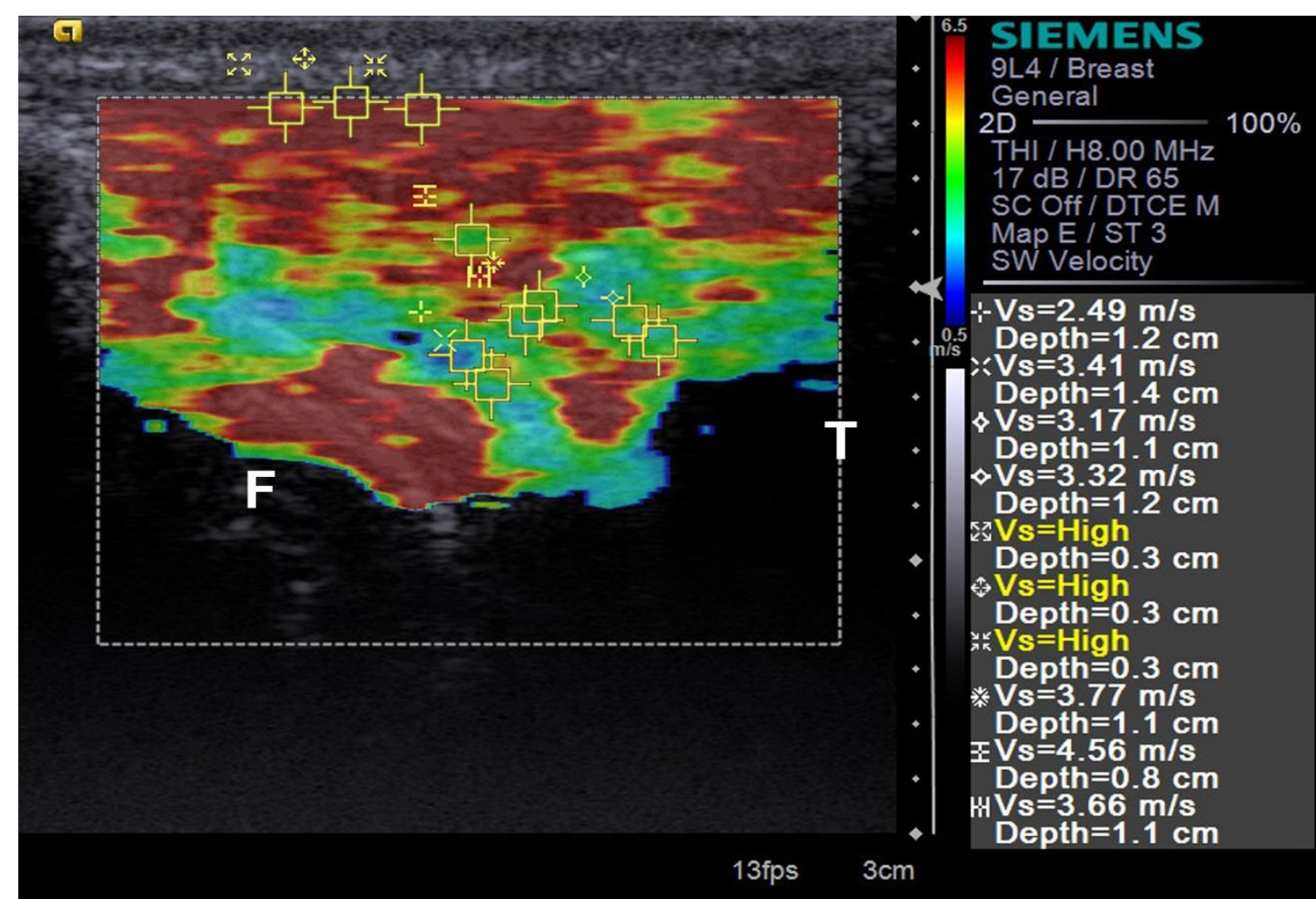

Figure 2. Elastographic image obtained in longitudinal view of a semi-flexed canine stifle joint. Superficially, a linear region of red tones is noted, representing the patellar ligament. Beneath it, the intermediate stiffness (green) tissue refers to the infrapatellar fat, among which, the cruciate ligaments and softer tissues (blue tones) are found, the cranial one being filiform and located closer to the tibia (T) and the caudal one rounded and closer to the femur $(\mathrm{F})$. Regions of interest are represented by the yellow square contours with values identified in the box, with symbol legend.

\section{RESULTS}

Of the thirty dogs evaluated, G1 group was composed of six animals (between 7 and 8 months old) and G2 (between three and seven years old) and G3 (between ten and sixteen years old) groups of 12 dogs each. All animals were within appropriate body score to the breed. B-mode ultrasonography allowed identification of the patellar ligament, medial meniscus, cruciate ligaments (cranial and caudal) and subsequently, ARFI elastography was performed. In the quantitative study, the patellar ligament was the most rigid, with mean SWV of $6.52 \mathrm{~m} / \mathrm{s}$, followed by the caudal cruciate ligament $(\mathrm{SWV}=3.62 \mathrm{~m} / \mathrm{s})$, medial meniscus $(\mathrm{SWV}=3.39 \mathrm{~m} / \mathrm{s})$ and cranial cruciate ligament $(\mathrm{SWV}=3.12 \mathrm{~m} / \mathrm{s})($ Table 1$)$. This sequence was maintained in all animals evaluated, even among groups regarding gender, fertility and age.

Table 1. Mean values ( \pm standard deviation) of $\operatorname{SWV}(\mathrm{m} / \mathrm{s})$ of the patellar ligament, caudal cruciate ligament, medial meniscus and cranial cruciate ligament of the stifle joint of healthy Beagles according to age

\begin{tabular}{lcccc}
\multicolumn{1}{c}{ Structure } & G1 & G2 & G3 & Total \\
\hline Patellar Ligament & $5.95 \pm 1.76$ & $6.441 \pm 1.07$ & $6.90 \pm 1.28$ & $6.52 \pm 1.36$ \\
Caudal Cruciate Ligament & $3.61 \pm 0.90$ & $3.49 \pm 0.50$ & $3.75 \pm 1.31$ & $3.62 \pm 0.98$ \\
Medial Meniscus & $3.38 \pm 1.08$ & $3.08 \pm 0.55$ & $3.70 \pm 1.04$ & $3.39 \pm 0.92$ \\
Cranial Cruciate Ligament & $3.07 \pm 0.62$ & $3.05 \pm 0.60$ & $3.23 \pm 0.66$ & $3.12 \pm 0.63$ \\
\hline
\end{tabular}

G1 - younger animals, 6 months to 1 year old; G2 - adults, 1 to 7 years old and G3 - older animals, over 7 years old. 
There was also a positive correlation between SWV and age of the animals $(\mathrm{P}=0.012)$, that is, the older the animals, the higher the SWV of the intra-articular structures. However, the caudal cruciate ligament and the medial meniscus showed lower SWV in the G2 group instead of G1
$(\mathrm{P}<0.05)$ (Table 1). It was noted that SWV of all evaluated structures were higher in females than in males, so that all ligaments demonstrated to be stiffer in neutered animals when compared to intact animals $(\mathrm{P}<0.05)$ (Table 2).

Table 2. Mean values ( \pm standard deviation) of SWV $(\mathrm{m} / \mathrm{s})$ of the patellar ligament, caudal cruciate ligament, medial meniscus and cranial cruciate ligament of the stifle joint of healthy Beagles according gender and reproductive status

\begin{tabular}{lrrrc}
\multicolumn{1}{c}{ Structure } & Males & Females & Intact & Neutered \\
\hline Patellar Ligament & $6.43 \pm 1.22$ & $6.73 \pm 1.63$ & $6.38 \pm 1.38$ & $6.85 \pm 1.26$ \\
Caudal Cruciate Ligament & $3.51 \pm 0.72$ & $3.87 \pm 1.36$ & $3.50 \pm 0.72$ & $3.89 \pm 1.36$ \\
Medial Meniscus & $3.28 \pm 0.91$ & $3.71 \pm 0.88$ & $3.40 \pm 1.00$ & $3.38 \pm 0.65$ \\
Cranial Cruciate Ligament & $3.02 \pm 0.55$ & $3.37 \pm 0.74$ & $3.01 \pm 0.56$ & $3.41 \pm 0.72$ \\
\hline
\end{tabular}

\section{DISCUSSION}

Elastography was demonstrated as a feasible and non-invasive technique in studying the stiffness of the canine stifle joint structures, performing only a physical restraint of the animals, besides being rapidly executed. To the author's knowledge, this is the first study regarding ARFI elastographic characteristics of the stifle joint of healthy dogs of different ages, which reinforces the importance of the information obtained. The greater stiffness of the structures observed in females when compared to males may justify the higher frequency of cranial cruciate ligament insufficiency in bitches, considering that there is an association between the disease and hormonal action interfering in the control of fibroblasts proliferation, which also justifies the association with reproductive status (Bach et al., 2015).

Qualitative elastographic findings demonstrated the patellar ligament as the most rigid ligament evaluated. In one study, the patellar ligament of dogs was considered soft using the sonoelastography technique (Piccionello et al., 2018), which differs from the results found in the present study and from studies performed evaluating the Achilles tendon in humans (De Zordo et al., 2009) and digital flexor tendons in horses (Lustgarten et al., 2014), where these structures were considered hard. However, physical differences between sonoelastography and ARFI elastography technique should be considered when interpreting these findings. Sonoelastography requires an external compression to evaluate tissue deformity, promoting an operator-dependent qualitative assessment of tissue elasticity, while ARFI elastography is a method that promotes a dynamic stress generating mechanical shear waves (acoustic radiation force), resulting in qualitative and quantitative evaluations of elastic characteristics of tissues (Gennisson et al., 2013; Sigrist et al., 2017). Thus, comparison of the results obtained from different techniques should be made with caution.

It is believed that the small difference in elasticity of the cruciate ligaments and the patellar ligament observed between animals from G1 and G2 is due do the fact that better ligament cell organization occurs when bone maturity is acquired. Similarly, aging leads to hyalinization and mineralization of ligament fibers, fibroblasts loss and remnant chondroid metaplasia, as well as disruption of collagen matrices (Vasseur et al., 1985).

The greater stiffness of the ligaments in older patients is justified both by the structural disorganization and the higher cell density, proven to compromise tissue elasticity (Vasseur $e t$ al., 1985). Besides, in the present study, the medial meniscus presented gradual and linear stiffening, probably due to its fibrocartilaginous composition and lower cell metabolism compared to the ligaments.

The present study provides reference values for elastographic parameters of the stifle joint structures of healthy Beagles, but it is known that degenerative diseases of the canine knee may present racial predisposition, such as, for example, a higher predisposition of cranial cruciate ligament insufficiency in large and giant breeds (Marques et al., 2014). Thus, this study has great value, because it is the first report of the 
elastographic characteristics of the stifle joint of healthy dogs of different ages, which might be used as basis for new studies involving different breeds.

Elastography has great importance in human medicine in assessing musculoskeletal diseases, such as tendinopathies of the Achilles tendon and patellar ligament (Pedersen et al., 2012; Ooi et al., 2016), as well as in veterinary medicine, in evaluating tendinous and ligament injuries in horses, allowing characterization of chronicity and severity of lesions (Lustgarten et al., 2015). Therefore, it is believed that the present study provides important information regarding the normal elastographic characteristics of the canine stifle joint components and further studies are necessary to determine reference values of other joints, as well as to investigate the diagnostic potential of the technique in dogs with musculoskeletal disorders.

\section{CONCLUSION}

Through elastography, characteristics of tissue stiffness of the stifle joint of healthy Beagles were obtained, observing the difference and elasticity between the components. Additionally, the technique allowed to verify the stiffness difference of these structures among age groups, demonstrating a decrease of elasticity with age. Considering that the exam is non-invasive and provides quantitative information regarding the structures that compose the joint, it is believed in the potential of the technique in evaluating other joints and its use might provide a promising future in veterinary orthopedics and rheumatology.

\section{ACKNOWLEDGEMENTS}

The present study was supported by FAPESP (São Paulo State Foundation Research) in the form thematic project (2017/14957-6), CNPq (National Council for Scientific and Technological Development) in the form productivity scholarship (process number 309199/2017-4) and CAPES (Higher Education Personnel Improvement) in the form of a Master's degree scholarship. The authors also thank Jair Matos from Siemens Healthineers for technical assistance.

\section{REFERENCES}

BACH, M.; JUNIOR, J.A.V.; TASQUETI, U.I. et al. A retrospective study of dogs with cranial cruciate ligament rupture: 32 cases (2006-2012). Semin. Ciênc. Agrár., v.36, p.1409-1418, 2015.

BENJAMINI, Y.; HOCHBERG, Y. Controlling the false discovery rate: a practical and powerful approach to multiple testing. J. R. Statist. Soc. B Methodol., v.57, p.289-300, 1995.

CHEN, D.G.D.; PEACE, K.E. Clinical trial data analysis using R. Boca Raton: CRC Press, 2010. [358p.].

DUVAL, J.M.; BUDSBERG, S.C.; FLO, G.L. et $a l$. Breed, sex and body weight as risk factors for rupture of the cranial cruciate ligament in young dogs. J. Am. Vet. Med. Assoc., v.215, p.811, 1992.

GENNISSON, J.L.; DEFFIEUX, T.; FINK, M. et al. Ultrasound elastography: principles and techniques. Diagn. Interv. Imaging, v.94, p.487495, 2013.

HOLDSWORTH, A.; BRADLEY, K.; BIRCH, S. et al. Elastography of the normal canine liver, spleen and kidneys. Vet. Radiol. Ultrasound, v.55, p.620-627, 2014.

LUSTGARTEN, M.; REDDING, W.R.; LABENS, R. et al. Elastographic characteristics of the metacarpal tendons in horses without clinical evidence of tendon injury. Vet. Radiol. Ultrasound, v.55, p.92-101, 2014.

LUSTGARTEN, M.; REDDING, W.R.; LABENS, R. et al. Elastographic evaluation of naturally occuring tendon and ligament injuries of the equine distal limb. Vet. Radiol. Ultrasound, v.56, p.670-679, 2015.

MARINO, D.J.; LOUGHIN, C.A. Diagnostic imaging of the canine stifle: a review. Vet. Surg., v.39, p.285-295, 2010

MARQUES, D.R.C.; IBAÑEZ, J.F.; NOMURA, R. Principais osteotomias para o tratamento da ruptura do ligamento cruzado cranial em cães revisão de literatura. Arq. Ciênc. Vet. Zool. UNIPAR, v.17, p.253-260, 2014.

MENDIBURU, F. Agricolae: statistical procedures for agricultural research. $\mathrm{R}$ package version 1.3-3. Available in: https://CRAN.Rproject.org/package=agricolae 2020. Accessed in: 03, julho, 2019. 
OOI, C.C.; RICHARDS, P.J.; MAFFULLI, N. et al. A soft patellar tendon on ultrasound elastography is associated with pain and functional deficit in volleyball players. J. Sci. Med. Sport, v.19, p.373-378, 2016.

PEDERSEN, M.; FREDBERG, U.; LANGBERG, H. Sonoelastography as a diagnostic tool in the assessment of musculoskeletal alterations: a systematic review. Ultraschall Med., v.33, p.441-446, 2012.

PETRIE, A.; WATSON, P. Statistics for veterinary and animal science. 3.ed. Hoboken: Wiley-Blackwell, 2013. 408p.

PICCIONELLO, A.P.; SERRANI, D.; BUSONI, V. et al. Sonoelastographic features of the patellar ligament in clinically normal dogs. Vet. Comp. Orthop. Traumatol., v.31, p.279-284, 2018.
PRADA, T.C.; MINTO, B.W.; PEREIRA, N.W. et al. Tratamento clínico da osteoartrite do joelho em cães. Investigação, v.17, p.16-23, 2018.

SIGRIST, R.M.; LIAU, J.; EL KAFFAS, A. et al. Ultrasound elastography: review of techniques and clinical applications. Theranostics, v.7, p.1303-1329, 2017.

VASSEUR, P.B.; POOL, R.R.; ARNOCZKY, S.P. et al. Correlative biomechanical and histologic study of the cranial cruciate ligament in dogs. Am. J. Vet. Res., v.46, p.184-197, 1985.

ZORDO, T.; FINK, C.; FEUCHTNER, G.M. et al. Real-time sonoelastography findings in healthy Achilles tendons. Am. J. Roentgenol., v.193, p.134-138, 2009. 